\title{
THE POSITION OF THE ADJUNCT OF PLACE IN THE SENTENCE
}

\section{Adelajda Baftiu}

\begin{abstract}
This study will address the adjunct of place expressed with prepositional phrases and the factors that influence its position in the sentence. The aim is quantitative analysis, through which the comparison is made between the three news in the newspaper "Koha ditore" and the commentary of the Barcelona / Real Madrid basketball match. A quarter of a game was analyzed from the commentary on the basketball game, while three news items were analyzed from the newspaper, trying to make the number of words approximately the same. From the first quarter 2439 words are used, while 2730 words are used from the three news items in the newspaper. The selection of different types of texts, spoken / written language, has been intentional, because through them it is intended to draw differences in the use of the adjunct of place. The prepositions were found through the KWIC program, then those constructions that function as adjunct of place were singled out, because with the same prepositions the adjunct of time, manner, purpose, etc. can come out. Adjuncts of place are treated in terms of their position in the sentence, along with the effect that each position has on these two texts, taking into account the context. The study links the field of syntax (sentence structure) with the field of discourse analysis, seeing context as one of the key elements of language selections. The questions on which this paper will be based are: what are the factors that influence the position of the adjunct of place in the sentence, are the circumstances important elements of the information structure and sentence structure.
\end{abstract}

So, based on the context, as one of the key points of this study, we see the position of the adjunct of place in two different types of texts. The initial position was seen to be more prevalent in the newspaper, where it served as a cohesive tool, as opposed to commenting on the game, where the adjunct of place was used in this position to express the new information. The position in the middle of the sentence was rarely used, this position was not related to any kind of focus, but there were changes in the structure of the sentence. In the final position, the adjuncts prevail in commenting the game. The commentary notes the absence of the key element of the sentence, the verb, which was covered by the adjunct, which was placed immediately after the subject, implying the verb from the context. Whereas, in the newspaper it appears less often than in commentary and this position is due to the usual model of word order in sentences in the Albanian language.

Keywords: syntax, discourse analysis, quantitative analysis, adjunct of place, context

\section{Introduction}

The adjunct of place has a special place in the grammar's books of Albanian, starting from the first grammars of Rrota (1942), of Prifti (1958), of Cipo (1952), until today's grammars books. The name for the adjunct of place does not appear the same in all authors; it comes with plotësor ndajfoljor, advërbjar and plotës. Rrota (1942) calls the determinations of the adjunct of the place, time, manner and of the cause Advërbjarë. A different name of the adjunct of place is found in Cipo (1952), who calls the adjunct plotës $i$ vendit. He notes that this complement indicates a physical place, but also a metaphorical place. Prifti divides the complements of the place 
ISSN 2661-2666 (Online) International Scientific Journal Monte (ISJM) DOI: https://doi.org/10.33807/monte.20211825 Volume 4, (No).1 (2021): April

into complements of genuine place, metaphorical or figurative place. According to him (1958: 133), the complement of the place with the prepositions $t e, t e k, k e$ are also used to indicate the person we are addressing or standing next to (are), for example: Unë banoj te tezja = Në shtëpi të tezes. Similar to previous authors, Dhima also (2005: 117) describes the adjuncts, but the syntagm: E kapi për krahu considers the adjunct of place, unlike the Academy of Syntax which reserves the first function of the object, and the second of the adjunct of place. Çeliku (2012: 177) makes a broader treatment of the adjunct of place, dividing them into necessary or complementary and facultative or additional.

Memushaj, Kananaj, Koleci and Turano treat the adjunct of place in the studies of generative syntax in the Albanian language. Koleci and Turano (2011) divide the elements of sentence into arguments and adjuncts. According to them, the necessary elements in the phrase are arguments, while the faculative ones are adjuncts. Kananaj calls the adjunct of place a component of the sentence structure that expresses concrete or abstract, static or dynamic spatial relationships and performs the function of peripheral or complement. She (2012: 180) emphasizes that in generative linguistics, for the adjuncts syntagm to form a maximum projection, the preposition must be followed by a complement and preceded by a specifier, ie: specifier + preposition + complement - që nga maja. Huddleston and Pullum (2002: 679-681) use the term location for the place domain, but also for the time domain, because the same prefixes can be used in both domains. According to them (ibid.), Place is expressed by adjuncts and complements, which are quite different in form and meaning. They consider the most elementary case of location to be the spatial location without moving from one place to another.

\section{Methodology}

This study analyzes two different types of texts: commentary on the Barcelona/ Real Madrid basketball match and the newspaper "Koha ditore", January 14, 2015. A quarter of a game was analyzed from the commentary on the basketball game, while three news items were analyzed from the newspaper, trying to make the number of words approximately the same. 2439 words are used from the first quarter of the game, while 2730 words are used from the three news items in the newspaper. The selection of different types of texts, spoken / written language, has been intentional, because through them it is intended to draw differences in the use of the adjunct of place. It is treated the adjunct of the place expressed with prepositional syntagm: preposition + noun / noun syntagm.

The prefixes were found through the KWIC program, and then those constructions that function as country contexts were singled out, because with the same prefixes the adjunct of time, manner, purpose, etc. can come out too. Adjuncts are treated according to their position in the sentence, together with the effect that each position has in these two texts, taking into account the context. According to Dijk (2008), context is the definition of relevant aspects of the communication situation by the participants. Further Dijk (ibid.) for the context states that: "Contexts are thus not some kind of objective condition or direct cause, but rather (inter)subjective constructs designed and ongoingly updated in interaction by participants as members of groups and communities".

\section{Analysis and results}


ISSN 2661-2666 (Online) International Scientific Journal Monte (ISJM) DOI: https://doi.org/10.33807/monte.20211825 Volume 4, (No).1 (2021): April

The initial position, according to Hasselgard (2010: 67), is the second most common position for Englishspeaking adjuncts. The most common adjuncts in this position are the adjuncts of time and place. Based on contextual factors, an adjunct can give new or old information, respectively the initial and final position in the sentence. Adjuncts in the initial position can indicate the cohesion and coherence of the text, if they contain anaphoric references or if they provide the necessary information for the whole sentence. Also, adjuncts can be placed in the initial position for stylistic reasons, such as syntactic parallelism or because they participate in the text strategy, providing a global text structure (Hasselgard 2010: 73). The initial position is considered the position in front of the subject and the verb. In the commentary of the sports match, out of 34 country circumstances (prepositional phrases) used, only two cases turn out to be in the initial position:

\section{Eg1: Nga ky kënd duket si një situatë diskutabile.}

In this example the adjunct is not necessary because the match of the game is seen by the audience but gives important details of the game. From the structural aspect of the sentence, here the adjunct of place is optional. On the other hand, in the newspaper from 29 adjuncts of place, a larger number of the use of adjuncts in this position appears, a total of 8 adjuncts of the place:

Eg2: Zvarritja e shërbimit ka bërë që të zgjatet lista e pritjes së pacientëve për CT dhe për pasojë ka detyruar ata të drejtohen në klinikat private. Tek to kanë paguar 150 euro në vend se të paguanin 25 euro sa kushton shërbimi i CTsë nё $Q K U K$.

From the point of view of the sentence, in both texts the adjunct is not an obligatory part of the sentence. It is worth mentioning that in the examples of the game the language choices depend on the context of the game development, while in the news the choices are premeditated, made according to a certain plan. In the newspaper it is noticed that the adjunct of place performs a completely different function, expressing the cohesion of the text, unlike the game, where the initial position was used to focus the new information. So, in the examples of the newspaper the adjunct of the place serves as a cohesive tool, the noun group klinike private is retrieved through the prepositional phrase tek to. It is seen that the initial position of the circumstances in these texts is determined by various contextual factors. The difference between spoken/ written language highlights these differences, because written language is more cohesive (expressed in grammatical and lexical forms) than spoken language, and one of the forms to express cohesion is the adjunct of place.

\section{The position of the adjunct in the middle of the sentence}

As a general rule, obligatory adjuncts are not placed in the middle of the sentence (Hasselgard 2010: 98103). In terms of information structure, the position in the middle of the sentence is not related to any kind of focus. Adjuncts are placed in the middle of the sentence, because the initial and final positions are reserved for other elements of the clause with informative value or higher syntactic weight. The middle position is considered any position between the subject and the necessary element of the sentence, which is the verb. In commenting on the game, the adjunct in this position is presented twice: 
ISSN 2661-2666 (Online) International Scientific Journal Monte (ISJM) DOI: https://doi.org/10.33807/monte.20211825 Volume 4, (No).1 (2021): April

Eg1. Filipe Rejes në bankën e tij, për të pushuar, kanë mbetur dy minuta e pesëmbëdhjetë sekonda përfindim të pjesës së pare.

In this example the sentence comes out without verbs, only with the subject and the adjunct. In this case the adjunct is obligatory (the verb though absent, is implied by the context, and the absence of the adjunct would make the sentence non-syntactic). As in the examples above, even in the newspaper the adjunct of place in the middle of the sentence is very rare, a total of three adjuncts of place occur. The following is an example found in the news:

Eg1. Klinikat private në vend dhe rajon kanë fituar rreth 2 mijë euro në ditë, apo rreth 1 milion euro brenda dy viteve.

In this example it is noticed that the sentence is complete and does not lack any important element, as in the example from the game commentary, in the sense that the sentence works even without the adjunct and still makes sense, but may be necessary from the point of view of the information provided.

\section{The position of the adjunct at the end of the sentence}

If an adjunct is placed in the initial or final position, then it has syntactic weight. The position at the end of the sentence is considered the position after the subject and the verb, even if other adjuncts emerge after the adjunct of place; it is still taken as the final position. This is the position most often encountered by the adjunct of place in the basketball game, out of 34 adjuncts of place, it is used 29 times:

Eg1. Bërryli vendoset në shpinë; Eg2. Llull, kundërsulm, Xhekson, pranë tij.

Even in these examples the influence of context on language selections is noticed. It is seen that in the first example the adjunct of place is expressed with body parts, so the exact specification of the place is important, because it sets the rules of the game. In the second example the verb is missing and the adjunct is directly related to the subject. In these two examples, both from the point of view of the sentence the text, the adjunct of place is necessary.

In the newspaper, out of 29 adjuncts of place, 17 appear in the final position:

Eg3. Dhjetëra qytetarë kanë protestuar për të dytën ditë me radhë para ndërtesës së KEDS-it për të kërkuar uljen e çmimit të energjisë elektrike.

In the newspaper the adjunct in this position also appears due to the usual model of sentence construction in the Albanian language. It was also said above that sentence constructions in written language in the newspaper are more complex compared to spoken language.

\section{Conclusion}

One of the key elements, which were taken into account to distinguish between the uses of the adjunct of place in different sentence positions, was the context. The context, treated according to Dijk's concept, was the definition of the relevant aspects of the communication situation by the participants. So, based on the context, as one of the key points of this study, we also see the position of the adjunct of place in two different types of texts. 
The initial position was seen to be more prevalent in the newspaper, where it served as a cohesive tool, as opposed to commentary of the game, where the adjunct of place was used in this position to express the new information. From the structural aspect of the sentence, in both texts the adjunct was a facultative element. The position in the middle of the sentence was rarely used, and this position was not related to any kind of focus, but there were changes in the structure of the sentence. In commentary of the game, the adjunct of place was a necessary element, because the sentence would be ungrammatical if the context was removed, e.g. Filipe Rejes,....për të pushuar, without the adjunct, në bankën e tij, the sentence would be meaningless.

On the other hand, the adjunct in the newspaper was not mandatory elements of the sentence. In the final position, the adjuncts prevail in commentary of the game. The commentary notes the absence of the key element of the sentence, the verb, which was covered by the adjunct, which was placed immediately after the subject, implying the verb from the context. So from this we conclude that from the structural aspect of the sentence, the adjunct is necessary. Whereas, in the newspaper the adjunct in this position came out less often than in the commentary and this position was taken due to the usual model of the order of words in the sentence in the Albanian language. 
ISSN 2661-2666 (Online) International Scientific Journal Monte (ISJM) DOI: https://doi.org/10.33807/monte.20211825

Volume 4, (No).1 (2021): April

\section{References}

1. Agalliu, Fatmir - Angoni, Engjëll - Demiraj, Shaban et al. (2002). Gramatika e gjuhës së sotme shqipe 1, ASHSH, Tiranë.

2. Çeliku, Mehmet (2012). Sintaksë e gjuhës shqipe, ILAR, Tiranë.

3. Dykro, Osvald - Todorov, Cvetan (1984). Fjalor enciklopedik $i$ shkencave të ligjërimit, Rilindja, Prishtinë

4. Hasselgard, Hilde (2010). Adjunct Adverbials in English, Cambrige University Press, New York.

5. Hudleston, Rodney - Pullum, Geoffrey (2002). The Cambridge Grammar Of the English language, Cambridge University Press.

6. Kananaj, Anila (2012). Funksionet e rrethanorit në gjuhën shqipe, disertacion i doktoratës, Universiteti i Tiranës, Tiranë.

7. Koleci, Flora - Turano, Giuseppina (2011). Hyrje në sintaksën gjenerative të shqipes, SHBLU, Tiranë.

8. Martinet, Andre (2002). Elemente të gjuhësisë së përgjithshme, Dituria, Prishtinë.

9. Prifti, Stefan (1959). Sintaksa e gjuhës shqipe, ETMMK, Tiranë.

10. Van Dijk, Teun. A (2008). Discourse and Context, Cambrige University Press, New York.

11. Rugova, Bardh (2014). Imazhi i shqiptarit dhe i Shqipërisë në "New York Times" në kohën e shpalljes së pavarësisë së Shqipërisë (1911-1913), Trembelat, Prishtinë.

12. Rugova, Bardh-Linditë Sejdiu-Rugova (2015). Hyrje në gramatikën e tekstit të gjuhës shqipe, Trembelat, Prishtinë.

13. Rugova, Bardh (2020). Gjuha e filmit, KOHA, Prishtinë.

14. Sejdiu-Rugova, Linditë (2019). Strukturë dhe funksion - Studime në sintaksë të shqipes, Trembelat, Prishtinë.

15. Sejdiu-Rugova, Linditë (2019). Klauzat e varura të përcaktuara sipas përmbajtjes në gjuhën angleze dhe korrespodencat e tyre në gjuhën shqipe, Parnas, Prishtinë.

16. Ismajli, Rexhep (2019). Bashkësi gjuhësore, njësi, varietet, ASHAK, Prishtinë. 